\title{
Competency Curriculum Intervention: Student Task Self-Efficacy and Attitudes in Child Welfare
}

\author{
Barbara Pierce \\ Taekyung Park
}

\begin{abstract}
Three cohorts of BSW and MSW Title IV-E and NCWWI student scholars ( $n=$ 125) were educated using a university-agency developed competency-based curriculum and field placement. In order to determine if this curriculum and field placement would improve perceived competence and attitudes toward child welfare work, pre and post-field placement surveys were used. Statistically significant change was demonstrated for most competencies. Attitudes toward child welfare work demonstrated no change from the favorable attitudes students had before entering their field placements. There were no statistically significant differences between BSW and MSW students. Students who had higher perceived competence endorsed motivation and intent to remain in child welfare. Based on the findings, we recommend key strategies to keep up the morale of BSW and MSW graduates in child welfare agencies: transition-to-work initiatives by schools, mentoring programs by agencies, manageable caseloads, and the application of skills and knowledge learned.
\end{abstract}

Keywords: Child welfare students; competencies; task self-efficacy; work attitudes

For too long social work organizations that specialize in public child welfare have faced considerable difficulties in recruiting and retaining qualified, experienced practitioners. As a result, the ability of organizations to provide effective services to their clients may be compromised (Daly, Dudley, Finnegan, Jones, \& Christiansen, 2001). While the status quo of public child welfare invites many, often conjectural explanations, the hereand-now of how to curb or even to fix the endemic turnover in public child welfare demands increased vigilance and attention. Through their research, Ellett, Ellis, Westbrook, and Dews (2007) have already established the structural persistence of such turnover. Willis, Chavkin, and Leung (2016) agree but go a step further to indicate that turnover is to be expected for a variety of reasons, some of which can be healthy for the agency. These authors describe means by which agencies work not to cut the rates of turnover but to reduce its impact on the agency. Their study does not necessarily take into account the disruption to children and families when they lose a caseworker for reasons such as low pay or high caseloads. The negative impact of turnover on children in the foster care system is well-documented. For example, Flower, McDonald, and Sumski (2005) indicate that higher permanency outcomes for children occur when they have the same caseworker throughout their time with the agency.

Much of the research on turnover and retention strategies has addressed two key concerns: the importance of retaining highly educated and skilled workers; and, absent that, the negative impacts on the worker, client, and agency experience in the wake (Mor Barak, Nissly, \& Levin, 2001). As noted above, Flower and colleagues (2005) established that

Barbara Pierce, PhD, LCSW is an Associate Professor, School of Social Work, 902 West New York Street, Indiana University, Indianapolis, IN 46202. Taekyung Park, MSW, is a doctoral student, School of Social Work, 902 West New York Street, Indiana University, Indianapolis, IN 46202.

Copyright (c) 2017 Authors, Vol. 18 No. 2 (Fall 2017), 490-506, DOI: 10.18060/21394 
permanency outcomes for children (74.5\% of the cases) are much higher when the same caseworker follows a client from start-to-finish. Without that consistency, negative effects quickly surface in ways that impede social workers from remaining on-the-job. First, there is the physical toll: because the existing workforce is often required to assume the responsibilities and assignments of departed workers, workloads tend to balloon beyond the limits of what can be accomplished conscientiously and effectively (Webb \& Carpenter, 2011). As a result, the performance level of those still employed lessens (Iglehart, 1990). A second issue is the emotional toll: because the morale of colleagues left behind in these circumstances suffer, stress, burnout, and trauma routinely fill the vacuum (Iglehart, 1990). Agencies that must endure the loss of employees also suffer, particularly in terms of direct and indirect costs (Lambert, Cluse-Tolar, Pasupuleti, Prior, \& Allen, 2012). Mor Barak et al. (2001) have grouped the direct costs of employee turnover into three categories: "separation costs (exit interviews, administration, functions related to terminations, separation pay, and unemployment tax); replacement costs (communicating job vacancies, pre-employment administrative functions, interviews, and exams); and training costs (formal classroom training and on-the-job instruction)" (p. 627). Retention, then, precludes these negative effects and preserves those limited resources that agencies can ill-afford to spend on processes better avoided. The best benefit is that families will receive the services they need from the seemingly simple act of keeping caseworkers on the job, which allows for caseworkers to get to know families better and to shepherd them through the successful completion of a case plan.

Research on child welfare worker's turnover or retention and attitudes toward the work has identified more than 20 factors that impact turnover including job satisfaction, selfefficacy, organizational commitment, work conditions, supervisor support, stress, secondary trauma, etc. (Landsman, 2008; Mor Barak et al., 2001). Of those, job satisfaction was identified as a direct predictor of turnover or retention among child welfare workers (Chen \& Scannapieco, 2010; Ellett et al., 2007; Hopkins, Cohen-Callow, Kim, \& Hwang, 2010; Levy, Poertner, \& Lieberman, 2012; Strolin-Goltzman, 2010). Low job satisfaction has a negative impact on employee's desire to stay and commit to child welfare work.

While we know much about workers attitudes regarding job satisfaction and retention behavior, less is known about pre-service student attitudes and behaviors with regard to attitudes toward working in child welfare or perceived self-efficacy. This paper aims to enhance knowledge about social work students by testing one means of correcting the turnover problem, that is, by implementing competency-based education for social work students, thereby increasing self-confidence, and ultimately self-efficacy. The literature appears to link self-efficacy and attitudes toward child welfare work and retention in the child welfare workforce (Ellett, 2000; Jayaratne \& Chess, 1984; Siefert, Jayaratne, \& Chess, 1991; Tracy, Bean, Gwatkin, \& Hill, 1992). Thus, we expect that graduating students with high self-efficacy and favorable attitudes toward working in child welfare may enhance retention. 


\section{Literature Review}

\section{Self-Efficacy}

Self-efficacy has been defined as "beliefs in one's capabilities to organize and execute the courses of action required to produce given attainments" (Bandura, 1997, p. 3). Not surprisingly, it also comprises matters of competence. Hughes, Galbraith, and White (2011) contended that self-efficacy signifies the cognitive perception of competence, which bear comparison with Pajares and Schunk (2002), who noted that perception of self-efficacy answers "Can I" questions. Additional refinements have appeared in the literature. Maddux (1995) recognized the need to partition self-efficacy into task self-efficacy and coping selfefficacy. Task self-efficacy evinces the simple ability to perform a task, while coping selfefficacy figures as grace under pressure: the confidence needed to perform well under challenging circumstances (Rogers, Markland, Selzler, Murray, \& Wilson, 2014). The current study defines task self-efficacy as the perceived competence to perform a task ably.

Self-efficacy, as an agent of retention, has benefited from its established and recognized association with intent to remain and attitudes about working in child welfare (Ellett, 2000; Jayaratne \& Chess, 1984; Siefert et al., 1991; Tracy et al., 1992). For social workers, acquisition of the knowledge and skill to produce an outcome starts in the social work educational program and becomes fully realized in the agency. Ellett (2000) surveyed 941 public child welfare workers in Arkansas and Louisiana regarding intent to remain employed. Intent to remain employed was positively correlated with human caring, selfefficacy, and perception of a professional organizational culture (administrative support). Intent to remain employed was negatively correlated with professional organizational culture deprivation (lack of professionalism and commitment). The study also demonstrated that those workers with social work degrees had higher scores on measures of intent to remain. Similarly, Cole, Panchanadeswaran, and Daining (2004) randomly surveyed 500 Maryland social workers. Based on 232 responses of workers who completed surveys on perceived workload, efficacy, and job satisfaction, they observed that higher levels of perceived efficacy were correlated with higher job satisfaction. In addition, Cole and colleagues (2004) found that "perceived efficacy mediated the relationship between perceived workload and job satisfaction” (p. 8). We may reasonably conclude that lack of self-efficacy indeed looms as one reason why those new workers with high caseloads and little experience are often the first to leave agencies.

With the support of Title IV-E funding, public child welfare agencies and child welfare educators mapped a strategic course to provide consistency in quality child welfare services by recruiting and retaining qualified child welfare workers (Hartinger-Saunders \& Lyons, 2013). This funding became available in the 1980s and provides scholarships to students in publicly funded social work programs who wish to work in public child welfare in exchange for a required number of years of payback employment to a public child welfare agency (Zlotnik, 2002). Studies designed to investigate the effectiveness of Title IV-E programs via the retention rates of those workers who graduated from its programs have confirmed that stipend program graduates were and continued to be more likely to stay in public child welfare after the required service years (Ellett et al., 2007). Both the stipends and field placements provided to social work students interested in child welfare have 
served as a useful incentive in the field of child welfare. Overall, then, evidence appears to demonstrate that Title IV-E programs assist agencies to retain caseworkers (Dickinson \& Perry, 2003; Gansle \& Ellett, 2003; Jones \& Okamura, 2000; Rosenthal \& Waters, 2006). Money alone, however, does not give a full picture of the success of Title IV-E programs.

When they gain child welfare knowledge and practice through field placements, social work students develop confidence in their ability to practice. In fact, Jones and Okamura (2000) found Title IV-E program graduates scored higher than non-Title IV-E graduates in work knowledge and confidence in child welfare. Building on past successes of Title IVE, additional funding from the National Child Welfare Workforce Institute (NCWWI) via the US Children's Bureau (Strand, Dettlaff, \& Counts-Spriggs, 2015) allows for more flexible use of funds in support of developing and enhancing university-agency partnerships to educate students and provide leadership for the development of innovations to recruit and retain child welfare workers.

\section{Student Attitudes Toward Child Welfare Work}

The literature on student perceptions or attitudes toward child welfare work is sparse. Perry (2004) found that MSW students who were interested in working in public child welfare wanted to work with economically disadvantaged populations and had personal growth goals. Seroka and Zugazaga (2008) reported high student satisfaction with their internships and subsequent placements and found high overall satisfaction levels particularly among the white students. Nearly three-quarters (74\%) of all graduates intended to remain employed in the child welfare field. Alperin (1998) noted that satisfaction with the internship was the largest predictor of intent to accept employment at a child welfare agency. Other studies on MSW graduates who were specially educated through Title IV-E programs revealed that Title IV-E participants were better equipped with knowledge and skills necessary for the work and provided better outcomes than their counterparts (Bagdasaryan, 2012; Leung \& Willis, 2012; Williams, Kirk, \& Wilson, 2011). Leake, DeGuzman, Rienks, Archer, and Potter (2015) likewise found high levels of satisfaction among NCWWI partnership trainees upon final evaluation. Traineeship students felt "ready" for the job (Leake et al., 2015, p. S310). However, some Title IV-E graduates reported that their newly acquired skills were not put to good use in their agencies when they return to work (Fitch, Parker-Barua, \& Watt, 2014). New social workers in child welfare agencies report that high caseloads too soon after initial employment was a key predictor of their leaving the job (Weaver, Chang, Clark, \& Rhee, 2007). Studies on student attitudes toward child welfare work and what it might take to persist or remain employed were not evident in the literature.

\section{Competency-Based Curriculum}

According to Council on Social Work Education (CSWE, 2015), "Competencies are measurable practice behaviors that are comprised of knowledge, values, and skills” (p. 3). School of social work are expected to increase students' knowledge, values, and skills along with confidence in the ability to do the job. Competency education is thought to improve the ability of learners to actually perform more accurately and professionally. Social work programs began to teach from a formally developed competency-based 
curriculum in 2008 when the Council on Social Work Education released the Educational Policy and Accreditation Standards (EPAS) outlining core competencies for social work education (CSWE, 2015). These competencies were to be measured at least partly in the field where students are observed actually practicing the desired competency. At the same time, some states and universities began to identify core competencies for child welfare practice (Clark, 2003). California's child welfare partnership, known as California Social Work Education Center (CalSWEC), developed competencies in the 1990s with other states following suit (Clark, 2003). Measuring competence with child welfare across the country is difficult as there is no one set of core competencies for child welfare such as there is for general social work education (Leake et al., 2015).

Leake et al. (2015) defined a set of child welfare competencies and evaluated perceived competence for NCWWI students nationally and demonstrated increased perceived competence in the NCWWI traineeship student population. The state child welfare agency in Louisiana partnered with seven public universities to develop a common set of competencies based on the CaLSWEC competencies but tailored for the education of Title IV-E and NCWWI students. This study assessed changes in perceived competence and in attitudes toward child welfare work in this student population.

\section{Methods}

The aim of this study was to identify potential growth in perceived competence and changes in attitudes toward child welfare work from pre-to-post field placement. Seven universities and the state agency developed and implemented a mutually agreed-upon set of competencies in their child welfare curriculum. All universities transparently demonstrated where in their curriculum specific competencies were met and all agreed to use the same field evaluation tools. Of note is the knowledge that the state agency was undergoing a massive leadership overhaul that created increased turnover and other workforce issues within the agency. All members of the partnership agreed to continue, however, with the use of the competency-based curriculum. The general line of inquiry included testing the effect of the competency-based curriculum on students' perceived competence and analyzing student attitudes toward the work.

Within this evaluation study, we hypothesized that: 1 . Overall students will show increased confidence in competence from pre-to-post internship; 2. Student attitudes toward doing the job of child welfare work from pre-to-post will diminish due to agency workforce issues; 3 . Students with higher perceived confidence in competence will have more positive attitudes toward child welfare work; and 4. there will be no difference between MSW and BSW graduates in competence and attitudes toward child welfare work. University Institutional Review Board permission was granted for the conduct of this study.

\section{Participants}

Three cohorts of student social workers over three years $(n=125)$ in child welfare programs at seven universities in Louisiana were asked to participate in the survey. All used the same set of university-state agency developed child welfare competencies. Both BSW ( $n=58)$ and MSW ( $n=35)$ students were included in this study. Thirteen students did 
not report their programs. The sample comprised Title IV-E scholars $(n=76)$ as well as students selected to receive National Child Welfare Workforce Institute (NCWWI) stipends $(n=49)$. There was no appropriate comparison group as all child welfare students in one state participated in this study. Given that the state partner had a vested interest in having trained employees at the end of the educational intervention, random assignment (perhaps by school) was not acceptable.

\section{Design and Data Collection}

This study used a pre-post survey design. In order to assess student attitudes toward child welfare as a field of practice, for purposes of recruitment and retention and perceived competence, all child welfare students (Title IV-E and Scholars) completed a survey prior to the start of their field placements and again at the completion of placements. Students beginning their final field placement completed their pre-survey at one of two regional orientations at the beginning of the fall semester, at which time they also completed a basic demographics inquiry. The post-survey was administered prior to graduation in either December (when necessary to accommodate those institutions that had December graduations) or April (immediately prior to May graduations).

\section{Measures and Data Analysis}

A 13-item scale mirroring the state competencies was developed to measure the degree of students' perceived confidence in their ability to answer the "Can I" question. That is, "How confident am I that I can do a particular competency measure”. Degree of perceived competence was used in this study to operationalize task self-efficacy. The scale asked students to assess their ability to meet the identified competencies using a seven-point Likert-type scale with responses ranging from 1 (no confidence) to 7 (complete confidence). For the attitude variable, a 10-item scale was developed to measure attitudes toward child welfare work. This scale also used a seven-point Likert-type rating, ranging from 1 (strongly disagree) to 7 (strongly agree). Cronbach's Alpha determined reliability coefficients of 0.9 for the competency survey and 0.8 for attitude toward child welfare work.

Relevant statistics included descriptive statistics and paired-t tests to identify overall change from pre- to post- on each scale. The Bonferroni correction was applied to minimize Type-I errors due to multiple tests. As computed for both scales, the significance level at 95\% confidence using the Bonferroni correction was 0.004. Multiple Linear Regression analyses determined the relationships between students' confidence level and attitudes toward public child welfare and an independent samples $t$-test measured differences between BSWs and MSWs.

\section{Results}

A total of 125 Title IV-E and NCWWI Scholar students completed the internship in this state during the test period. However, only 115 completed the pre-survey and 93 completed the post- survey process. Differences in graduation times may account for the loss of some data (December vs. May). The mean age of respondents was 28 ( $S D=8.6)$, 
61.1\% were below 25 years, 91.5\% were female, and 68.8\% were African American. Of these, $60.2 \%$ completed internships in rural communities, $62.4 \%$ obtained the BSW, and $37.6 \%$ completed the MSW. Most students had no previous child welfare experience. Students came from the seven participating Title IV-E child welfare programs in social work schools in the state, which includes two Historically Black Colleges and Universities (HBCU). See Table 1.

Table 1. Characteristics of Post-Survey Study Participants ( $n=93$ )

\begin{tabular}{|c|c|c|c|c|}
\hline & \multicolumn{3}{|c|}{ Frequency (\%) } \\
\hline & & BSW & MSW & Total \\
\hline \multirow[t]{3}{*}{ Age } & Below 25 \& 25 & $43(46.0 \%)$ & 14 (15.1\%) & 57 (61.1\%) \\
\hline & Over 25 & 15 (16.1\%) & 21 (22.6\%) & 36 (38.7\%) \\
\hline & Total & $58(62.4 \%)$ & 35 (37.6\%) & $93(100 \%)$ \\
\hline \multirow[t]{3}{*}{ Gender } & Female & $52(56.0 \%)$ & 33 (35.5\%) & 85 (91.5\%) \\
\hline & Male & 5 (5.4\%) & 2 (2.2\%) & 7 (7.6\%) \\
\hline & Total & 57 (61.3\%) & 35 (37.6\%) & $92(100 \%)$ \\
\hline \multirow[t]{4}{*}{ Ethnicity } & African American & $40(43.0 \%)$ & 24 (25.8\%) & 64 (68.8\%) \\
\hline & Caucasian/White & 18 (19.4\%) & 10 (10.8\%) & 28 (30.1\%) \\
\hline & Other & & 1 (1.1\%) & 1 (1.1\%) \\
\hline & Total & 58 (62.4\%) & 35 (37.6\%) & $93(100 \%)$ \\
\hline \multirow[t]{3}{*}{ Internship Place } & Urban & 27 (29.0\%) & 10 (10.8\%) & 37 (39.8\%) \\
\hline & Rural & 31 (33.3\%) & 25 (26.9\%) & $56(60.2 \%)$ \\
\hline & Total & $58(62.4 \%)$ & $35(37.6 \%)$ & $93(100 \%)$ \\
\hline
\end{tabular}

\section{Competence}

Paired $t$ tests were conducted to identify differences between pre- and post-measures of attitudes toward child welfare work. The Bonferroni Correction was applied to decrease Type 1 errors due to multiple tests. The adjusted alpha was 0.004 .

Hypothesis one states that overall students will report higher confidence in competence from pre-to-post internship. Overall, students reported a relatively high confidence level in their ability to meet the child welfare competencies by post-test. Students also reported an increase in confidence from pre- to post-survey. The overall mean for the competency scale on the pre-survey was $68.20(S D=14.37)$; whereas the mean for the post-survey was 74.52 $(S D=9.65)$. A statistically significant increase in confidence occurred from pre- to posttesting, $t(92)=-4.27, p .<.001$. Thus, hypothesis one was supported. Although increases for most individual items appeared, only eight items reached statistical significance individually after the adjusted alpha level was applied. The eight items were: understanding social work values; history of child welfare; writing court reports; assessing risk to children; making sound placement decisions; knowing different supervisory styles; successfully engaging with a parent; and analyzing, formulating, and influencing social policy. Students rated themselves as least confident in working with the courts. Ability to testify in court demonstrated a drop in confidence after students had the actual experience of attending court in their field placements; still, the result was not statistically significant ( $M 1=4.80$, $M 2=4.82$ ). Of the competencies that did see statistically significant growth, writing court reports remained the one that students felt least confident in being able to do ( $M 1=4.23$, 
$M 2=4.99)$. Students felt most confident in their ability to understand social work values and ethics ( $M 1=5.86, M 2=6.35)$.

We tested effect size using Cohen's $d$. Effect sizes of 0.5 to 0.7 indicate moderate effect size and 0.8 and above are considered large. The overall effect size was .40, which is a small effect size. Individually engaging, assessing risk, making sound placement decisions, and understanding social work values and ethics showed the highest effect sizes in this sample. All were in the moderate range (see Table 2).

Table 2. Pre/Post-tests Difference in Perceived Confidence

\begin{tabular}{|c|c|c|c|c|c|}
\hline \multirow[b]{2}{*}{ Confidence } & \multicolumn{2}{|c|}{ Mean (SD) } & \multirow{2}{*}{$\begin{array}{c}\text { Cohen's } \\
\quad d\end{array}$} & \multirow[b]{2}{*}{$t$} & \multirow[b]{2}{*}{ Sig. } \\
\hline & Pre $(n \approx 93)$ & Post $(\mathrm{n} \approx 93)$ & & & \\
\hline Apply critical thinking skills & $5.67(1.01)$ & $5.94(0.88)$ & -0.29 & -2.2 & 0.03 \\
\hline $\begin{array}{l}\text { Understand the social work } \\
\text { values }\end{array}$ & $5.86(1.05)$ & $6.35(0.71)$ & -0.55 & 4.45 & $<.001^{*}$ \\
\hline Apply strategies of advocacy & $5.46(1.12)$ & $5.74(1.03)$ & -0.26 & -2.12 & 0.04 \\
\hline $\begin{array}{l}\text { Understand the history of } \\
\text { child welfare }\end{array}$ & $5.27(1.36)$ & $5.85(1.06)$ & -0.48 & 4.07 & $<.001^{*}$ \\
\hline Write court reports & $4.23(1.89)$ & 4.99 (1.6) & -0.43 & -4.17 & $<.001 *$ \\
\hline Testify in court & $4.8(1.77)$ & $4.82(1.54)$ & -0.01 & 0.16 & 0.87 \\
\hline $\begin{array}{l}\text { Understand and can work } \\
\text { with Family Group Decision- } \\
\text { making }\end{array}$ & $5.58(1.24)$ & $5.83(0.97)$ & -0.22 & -2.03 & 0.05 \\
\hline Assess the risk to children & $5.18(1.49)$ & $5.89(0.95)$ & -0.57 & 4.55 & $<.001^{*}$ \\
\hline $\begin{array}{l}\text { Make sound placement } \\
\text { decisions }\end{array}$ & $5.17(1.51)$ & $5.99(0.82)$ & -0.67 & -5.14 & $<.001^{*}$ \\
\hline $\begin{array}{l}\text { Make adaptations to work } \\
\text { with families }\end{array}$ & $5.77(1.2)$ & $6.1(0.83)$ & -0.32 & 2.39 & 0.02 \\
\hline $\begin{array}{l}\text { Know different supervision } \\
\text { styles }\end{array}$ & $5.02(1.55)$ & $5.62(1.15)$ & -0.44 & -2.96 & $<.001^{*}$ \\
\hline $\begin{array}{l}\text { Successfully engage with a } \\
\text { parent }\end{array}$ & $5.22(1.5)$ & $5.92(0.97)$ & -0.55 & -4.62 & $<.001^{*}$ \\
\hline $\begin{array}{l}\text { Analyze, formulate and } \\
\text { influence social policy }\end{array}$ & $4.96(1.53)$ & $5.5(1.14)$ & -0.38 & 3.3 & $<.001^{*}$ \\
\hline Overall Mean & $68.2(14.37)$ & $74.52(9.65)$ & -0.4 & -4.27 & $<.001 *$ \\
\hline
\end{tabular}

* Statistically significant at 95\% confidence with Bonferroni Correction (p. $</=.004)$. SD: Standard Deviation

\section{Attitudes About Working in Child Welfare}

Paired $t$ tests were conducted to identify differences between pre- and post-survey for attitudes. The Bonferroni Correction was applied to decrease Type 1 errors due to multiple tests. The adjusted alpha was 0.004 .

Hypothesis two states that there will be a negative change in attitude from pre to post survey. Attitudes about working in child welfare were actually positive and remained so over the course of the internship. The overall mean for the attitude survey was not 
statistically significantly different from pre- to post-testing $t(90)=.26, p=.79$ and there were no individual items in which the pre to post scores were statistically significant. Thus, hypothesis two was not supported. Means were high indicating positive attitudes remained stable over the course of the internship. While decreases in means existed in some categories, the differences were not statistically significant (See Table 3).

Concerning single items for this survey, students remained motivated and persistent in helping children and families ( $M 1=6.32, M 2=6.38)$; rebounded and persisted after setbacks ( $M 1=5.93, M 2=6.00)$; were proud of their work $(M 1=6.43, M 2=6.52)$; felt confident in their abilities ( $M 1=6.25, M 2=6.34)$; felt personal accomplishment $(M 1=6.43, M 2=6.38)$; continued to want to help others $(M 1=6.80, M 2=6.80)$; and believed that child welfare work offered opportunities to make a difference $(M 1=6.72, M 2=6.62)$. Students were also concerned that some clients did not receive the services they deserved ( $M 1=6.39$, $M 2=6.40$ ). Students were asked if they would delay personal plans to help a client and in fact they continued to endorse that attitude but were not as inclined to do so ( $M 1=6.14$, M2=5.90).

Table 3. Pre/Post-test Differences in Perceptions of Child Welfare Work

\begin{tabular}{|c|c|c|c|c|}
\hline \multirow[b]{2}{*}{ Perceptions of Child Welfare Work } & \multicolumn{2}{|c|}{ Mean (SD) } & \multirow[b]{2}{*}{$t$} & \multirow[b]{2}{*}{ Sig. } \\
\hline & Pre $(n \approx 91)$ & Post $(\mathrm{n} \approx 91)$ & & \\
\hline I feel I am working hard but rarely see results. & $5.25(1.43)$ & $5.12(1.47)$ & -0.75 & 0.46 \\
\hline $\begin{array}{l}\text { I remain motivated and persist in helping } \\
\text { children and families. }\end{array}$ & $6.32(1.04)$ & $6.38(0.74)$ & 0.56 & 0.59 \\
\hline $\begin{array}{l}\text { I rebound and persist after setbacks in efforts } \\
\text { to accomplish goals. }\end{array}$ & $5.93(1.37)$ & $6(0.74)$ & -0.44 & 0.66 \\
\hline I am proud of my work. & $6.43(1.01)$ & $6.52(0.65)$ & 0.81 & 0.42 \\
\hline $\begin{array}{l}\text { I am confident in my ability to perform } \\
\text { services in Child Welfare. }\end{array}$ & $6.25(1.12)$ & $6.34(0.79)$ & -0.69 & 0.49 \\
\hline $\begin{array}{l}\text { I feel a sense of personal accomplishment } \\
\text { through my work. }\end{array}$ & $6.43(0.96)$ & $6.38(0.76)$ & -0.39 & 0.71 \\
\hline $\begin{array}{l}\text { I chose this profession because I want to help } \\
\text { others. }\end{array}$ & $6.8(0.76)$ & $6.8(0.48)$ & 0 & 1 \\
\hline $\begin{array}{l}\text { I would delay personal plans in order to help a } \\
\text { client who needs assistance. }\end{array}$ & $6.14(1.02)$ & $5.9(1)$ & -2.03 & 0.05 \\
\hline $\begin{array}{l}\text { It bothers me that some clients don't receive } \\
\text { the services they deserve. }\end{array}$ & $6.39(1.04)$ & $6.4(0.88)$ & -0.09 & 0.93 \\
\hline $\begin{array}{l}\text { I believe my work in child welfare will offer } \\
\text { opportunities to make a difference. }\end{array}$ & $6.72(0.8)$ & $6.62(0.63)$ & -1.12 & 0.27 \\
\hline Overall Mean & $62.07(7.86)$ & $62.38(5.21)$ & 0.26 & 0.79 \\
\hline
\end{tabular}

\section{Confidence and Attitudes toward Doing Child Welfare Work}

Hypothesis three stated that students with higher confidence in their competence would have more positive attitudes toward child welfare work. Linear regression was performed 
to evaluate how well confidence in child welfare work predicted students' attitudes toward the job. The correlation between perceived confidence in competence (task self-efficacy) and attitude toward the job was statistically significant $(r=.56, p .<.01)$. The regression equation for predicting students’ attitude toward the job was found to be $Y^{`}=39.9+.3 \times \mathrm{X}$. In this sample, $31 \%$ of the variance in attitudes toward the job can be explained by students' perceived confidence in their ability to meet the competencies. That is, the students who had high perceived confidence in their competence were more likely to have better attitudes toward the work of child welfare $\left(R^{2}=.32, \beta=.30, p<001\right)$. Thus, hypothesis three was supported.

\section{Differences Between BSW and MSW Students}

An independent samples $t$-test was used to determine whether level of education (BSW or MSW) made a difference in competence or attitude toward child welfare work. Findings demonstrated that for this sample there were no significant differences between MSWs and BSWs in perceived competence, $t(92)=1.258, p=.218$ ), or attitude toward child welfare work, $t(2)=1.301, p=.457$.

\section{Discussion and Implications}

Overall, this study demonstrates high levels of confidence in competence or task selfefficacy for most competencies and growth in most areas among BSW and MSW child welfare students. Further, attitudes toward child welfare work were positive and remained so throughout the field placement despite a difficult leadership transition at the agency. Students with higher perceived competence were more likely to have more positive attitudes toward the work of child welfare. There were no statistically significant differences between BSW and MSW students.

\section{Competence}

Overall, students' confidence in their ability to meet the competencies or task selfefficacy grew from pre- to post-survey. Students had the most confidence in their ability to understand social work values and ethics, a topic emphasized in their social work programs. They experienced growth in this area perhaps as they began to apply values and ethics in case situations in the field. Students experienced statistically significant change in perception of competence from pre to post in a positive direction. The field placements gave them experience to practice knowledge, values, and skills initially learned in the classroom. Students also reported growth from pre to post in their perceived confidence to write an effective court report as they were able to practice writing these reports with their field instructors. A decrease in perception of competence in testifying is not surprising. Working with the courts can be difficult, in light of the specialized vocabularies and procedures; nevertheless, enhanced training in this area would serve all parties well. As it turns out, those students who attended court with their field instructors actually lost confidence over the course of the internship, once the realities of how difficult testifying were demonstrated. Child welfare courses in schools of social work should therefore become more attentive to this dimension of social work practice by offering more 
instruction and practice in testifying in court before students engage in the actual field experience.

\section{Attitude Toward Child Welfare Work}

This study revealed no statistically significant differences from pre- to post-internship with regard to attitudes toward child welfare work. In this instance, non-significant results were considered positive. Students started out with positive attitudes and did not appear to lose their enthusiasm or desire to work with children and families in public child welfare. Although slight drops in attitude did occur, they were not statistically significant. Of note, this survey was conducted in a state that had experienced massive changes in the administration of the public child welfare agency during the time students were in their internships. Even though staff turnover increased, student attitudes remained high and positive. A number of possible reasons can account for their equanimity. First, students tended to be placed with field instructors who had worked in the public child welfare agency for several years. Those instructors may be considered as stayers, which likely translated into a more positive attitude about their work in general, which they then transmitted to students. Second, students were actively recruited to the Title IV-E and NCWWI programs and were mentored by child welfare faculty who approached the field with enthusiasm. Third, students did not have independent caseloads and thus did not have to bear the weight of that responsibility alone. Such burden, over time, sometimes comes with a price. At the beginning of the process, student attitudes were strong and remained positive.

\section{Task Self-Efficacy and Positive Perceptions of the Work}

Regression analysis revealed that students who had higher confidence in their competence were more likely to have positive perceptions about doing the work of child welfare. One of the items measured was intent to remain motivated to persist working with children and families and remain on the job. This result confirms previous findings of Cole et al. (2004), Ellett (2000), Siefert et al. (1991), Tracy et al. (1992), and Jayaratne and Chess (1984), all of whom demonstrated links between self-efficacy in ability and retention. Students and workers who feel competent or have high self-efficacy are more likely to remain motivated and to meet the challenges they face in the internship or workplace.

\section{Differences by Education}

In this study no differences were found in the areas of competency, or attitude toward child welfare work, that is, intent to remain in child welfare work, based on educational level or program. Perceived competence and intent to remain were high in our sample and echo the results of Ellett (2014) with regard to higher performance on standardized measures and remaining employed. While some literature has demonstrated a difference between BSWs and MSWs with regard to retention (Lewandowski, 1998; Nissly, Mor Barak, \& Levin, 2005), others found no difference (Rosenthal \& Waters, 2006). Our study compared attitudes along with perceived competence. Because these students were all exposed to the same educational competencies and similar curricula across programs and schools, it is not surprising that there are no statistically significant differences among these 
students. It is important to build strong competency-based curricula to help students to understand the realities of child welfare work.

\section{Implications}

Overall, the students in this study had statistically significant gains in perceived competence and began their final year in school with very positive attitudes toward the work of child welfare and ended with the same positive attitudes despite agency issues. These students appeared ready and willing to do the job as they graduated. Chances are many Title IV-E and NCWWI scholars have the same positive outlook and self-efficacy when they graduate from their social work programs. Yet, turnover remains a huge concern as we see graduates having caseloads too high too quickly (Weaver et al., 2007) and MSWs reporting that their education is not valued or put to good use in their agencies (Fitch et al., 2014). While educators seem to be doing a good job with competency education and keeping morale high while students are in school, they tend to lose track of their graduates after graduation. Transition-to-work initiatives may be helpful as faculty can remain somewhat involved with their students for a time after graduation in order to provide support and encouragement during the first year of employment. Agencies can facilitate a smooth transition to professional child welfare by offering mentoring programs for the first year of employment. Agencies should aim to keep caseloads down initially as students in public agencies rarely carry a full caseload and the new graduate must learn to manage a vast array of practice skills and responsibilities. Further, agencies who expend time and money in educating MSWs can elicit and encourage ideas from new graduates. This may help to keep morale high for the MSW graduate and enable agencies to benefit from new evidence-based approaches.

\section{Strengths and Limitations of the Study and Future Research}

The major strength of this study collected data on a student population (rather than agency workers) specifically by its inclusion of three cohorts from seven universities over the course of their internships. While there is no comparison group, this study reports on all of the child welfare scholars within a three-year period in one state. Its major limitation is that it only looks at perceptions of competence rather than actual demonstrated competence. The competency-based curriculum, however, was successfully implemented to improve students' perceived competence in child welfare. These students started their careers in child welfare with high task self-efficacy, in general. Another strength of this study is the further refining of the term self-efficacy by specifically using the term task self-efficacy and operationalizing it as perceived confidence in abilities or answering the "Can I" question.

Maturation, always a concern with pre-post designs, is certainly a limitation. Yet, the competency curriculum was reinforced throughout the curriculum and field placements so it seems likely that this intervention had a positive effect on students' perception of competence. Also, attitudes were highly positive to begin with and did not change over time. Creating a scale to measure self-efficacy and attitudes toward child welfare work is another limitation since there are existing scales for self-efficacy (Chen \& Scannapieco, 2010; Ellett, 2000; Hughes et al., 2011). Although reliability of those scales were tested 
and presented, further study needs to examine the validity of the scale. However, the measures in this study were developed specifically for child welfare workers. This aspect could have contributed to high Cronbach Alpha scores.

Future studies should examine both task and coping self-efficacy over the long-term in the transition from students to workers, particularly once the latter continue employment in their post-payback period. Approached that way, such a study could help establish a more certain longitudinal link between self-efficacy and attitudes toward child welfare work and possibly retention with a more refined understanding of self-efficacy. Selfefficacy, of course, faces repeated storms in the workplace. The key is in keeping it afloat and moving toward its port: continuity in work with children and families.

\section{Conclusion}

It is important for Title IV-E and NCWWI programs to evaluate workers' perceived competence as it may have an impact on future retention. This study aimed to identify differences in perceived competence and attitude toward child welfare work pre- to postfield placement after initiation of a statewide competency-based curriculum within seven state university child welfare programs. There were no differences among programs or level of education, perceived competence was improved, and attitudes toward the work were positive and remained so. Those with higher perceived competence appear to have more positive attitudes toward child welfare work. While this study used perceived competence as a measure of task self-efficacy, further work in refining self-efficacy measures for child welfare could enhance our knowledge of student and worker efficacy as students make the transition to full-fledged social workers in their agencies and begin the challenging work of caring for children and families.

\section{References}

Alperin, D. E. (1998). Factors related to student satisfaction with child welfare field placements. Journal of Social Work Education, 34, 43-54. doi: https://doi.org/10.1080/10437797.1998.10778904

Bagdasaryan, S. (2012). Social work education and Title IV-E program participation as predictors of entry-level knowledge among public child welfare workers. Children and Youth Services Review, 34(9), 1590-1597. doi: https://doi.org/10.1016/j.childyouth.2012.04.013

Bandura, A. (1997). Self-efficacy: The exercise of control. New York: W. H. Freeman \& Co.

Chen, S. Y., \& Scannapieco, M. (2010). The influence of job satisfaction on child welfare worker's desire to stay: An examination of the interaction effect of self-efficacy and supportive supervision. Children and Youth Services Review, 32(4), 482-486. doi: https://doi.org/10.1016/j.childyouth.2009.10.014

Clark, S. (2003). The California collaboration: A competency-based child welfare curriculum project for master's social workers. Journal of Human Behavior in the Social Environment, 7(1/2), 1-31. doi: https://doi.org/10.1300/J137v07n01_10 
Cole, D., Panchanadeswaran, S., \& Daining, C. (2004). Predictors of job satisfaction of licensed social workers: Perceived efficacy as a mediator of the relationship between workload and job satisfaction. Journal of Social Service Research, 31(1), 1-12. doi: https://doi.org/10.1300/J079v31n01 01

Council on Social Work Education. (2015). Educational policy statement. Alexandria, VA: Author. Retrieved from https://www.cswe.org/getattachment/Accreditation/Accreditation-Process/2015EPAS/2015EPAS_Web_FINAL.pdf.aspx

Daly, D., Dudley, D., Finnegan, D., Jones, L., \& Christiansen, L. (2001). Staffing child welfare services in the new millennium. San Diego, CA: San Diego State University, School of Social Work.

Dickinson, N. S., \& Perry, R. E. (2003). Factors influencing the retention of specially educated public child welfare workers. Journal of Health \& Social Policy, 15(3-4), 89-103. doi: https://doi.org/10.1300/J045v15n03_07

Ellett, A. J. (2000). Human caring, self-efficacy beliefs, and professional organizational culture correlates of employee retention in child welfare (Unpublished doctoral dissertation). Louisiana State University, Baton Rouge, LA.

Ellett, A. J. (2014). A first-hand account of Title IV-E child welfare initiatives in social work education and practice. Advances in Social Work, 15(1), 63-79.

Ellett, A. J., Ellis, J. I., Westbrook, T. M., \& Dews, D. (2007). A qualitative study of 369 child welfare professionals' perspectives about factors contributing to employee retention and turnover. Children and Youth Services Review, 29(2), 264-281. doi: https://doi.org/10.1016/j.childyouth.2006.07.005

Fitch, D., Parker-Barua, L, \& Watt, J. W. (2014). Envisioning public child welfare agencies as learning organizations: Applying Beer's viable system model to Title IVE program evaluation. Journal of Public Child Welfare, 8(2), 119-142. doi: https://doi.org/10.1080/15548732.2013.879089

Flower, C., McDonald, J., \& Sumski, M. (2005). Review of turnover in Milwaukee County private agency child welfare ongoing case management staff. Retrieved from http://legis.wisconsin.gov/lc/committees/study/2008/SFAM08/files/turnoverstudy.pdf

Gansle, K. A., \& Ellett, A. J. (2003). Child welfare knowledge transmission, practitioner retention, and university-community impact: A study of Title IV-E child welfare training. Journal of Health \& Social Policy, 15(3-4), 69-88. doi: https://doi.org/10.1300/J045v15n03 06

Hartinger-Saunders, R. M., \& Lyons, P. (2013). Social work education and public child welfare: A review of the peer-reviewed literature on Title IV-E funded programs. Journal of Public Child Welfare, 7(3), 275-297. doi: https://doi.org/10.1080/15548732.2013.798246

Hopkins, K. M., Cohen-Callow, A., Kim, H. J., \& Hwang, J. (2010). Beyond intent to leave: Using multiple outcome measures for assessing turnover in child welfare. 
Children and Youth Services Review, 32(10), 1380-1387. doi: https://doi.org/10.1016/j.childyouth.2010.06.006

Hughes, A., Galbraith, D., \& White, D. (2011). Perceived competence: A common core for self-efficacy and self-concept? Journal of Personality Assessment, 93(3), 278289. doi: https://doi.org/10.1080/00223891.2011.559390

Iglehart, A. P. (1990). Turnover in the social services: Turning over to the benefits. Social Services Review, 64(4), 649-657. doi: https://doi.org/10.1086/603801

Jayaratne, S., \& Chess, W. A. (1984). Job satisfaction, burnout, and turnover: A national study. Social Work, 29, 448-452. doi: https://doi.org/10.1093/sw/29.5.448

Jones, L. P., \& Okamura, A. (2000). Reprofessionalizing child welfare services: An evaluation of a Title IVE training program. Research on Social Work Practice, 10(5), 607-621. doi: https://doi.org/10.1177/104973150001000504

Lambert, E., Cluse-Tolar, T., Pasupuleti, S., Prior, M., \& Allen, R. (2012). A test of a turnover intent model. Administration in Social Work, 36, 67-84. doi: https://doi.org/10.1080/03643107.2010.551494

Landsman, M. J. (2008). Pathways to organizational commitment. Administration in Social Work, 32(2), 105-132. doi: https://doi.org/10.1300/J147v32n02_07

Leake, R., DeGuzman, A., Rienks, S., Archer, G., \& Potter, C. (2015). NCWWI traineeships: A national cross-site evaluation of child welfare stipend programs for ethnically diverse students. Journal of Social Work Education, 51(sup. 2), S299-316.

Leung, P., \& Willis, N. (2012). The impact of Title IV-E training on case outcomes for children serviced by CPS. Journal of Family Strengths, 12(1), 1-16.

Levy, M., Poertner, J., \& Lieberman, A. (2012). Work attitudes and intention to quit among workers in private child welfare agencies operating under performance-based contracts. Administration in Social Work, 36(2), 175-188. doi: https://doi.org/10.1080/03643107.2011.564723

Lewandowski, C. A. (1998). Retention outcomes of a public child welfare long-term training program. Professional Development, 1(2), 38-46. Retrieved from http://www.utexas.edu/research/cswr/survey/journal/articles/010204.pdf

Maddux, J. E. (1995). Looking for common ground: A comment on Kirsch and Bandura. In J. E. Maddux (Ed.), Self-efficacy, adaptation, and adjustment (pp. 377-385). New York: Plenum. doi: https://doi.org/10.1007/978-1-4419-6868-5_14

Mor Barak, M., Nissly, J., \& Levin, A. (2001). Antecedents to retention and turnover among child welfare, social work, and other human service employees: What can we learn from past research? A review and metanalysis. Social Service Review, 75, 625661. doi: https://doi.org/10.1086/323166

Nissly, J., Mor Barak, M. E., \& Levin, A. (2005). Stress, support, and workers' intentions to leave their jobs in public child welfare. Administration in Social Work, 28(5), 548577. doi: https://doi.org/10.1300/J147v29n01 06 
Pajeres, F., \& Schunk, D. H. (2002). Self and self-belief in psychology and education: A historical perspective. In J. Aronson (Ed.), Improving academic achievement: Impact of psychological factors on education (pp. 5-21). London, England: Academic. doi: https://doi.org/10.1016/B978-012064455-1/50004-X

Perry, R. (2004). Factors influencing MSW students' interest in public child welfare. Journal of Human Behavior in the Social Environment, 10(2), 1-31. doi: https://doi.org/10.1300/J137v10n02_01

Rogers, W.M., Markland, D., Selzler, A, Murray, C., \& Wilson, P. M. (2014). Distinguishing perceived competence and self-efficacy: An example from exercise. Research Quarterly for Exercise \& Sport, 85(4), 527-539. doi: https://doi.org/10.1080/02701367.2014.961050

Rosenthal, J. A., \& Waters, E. (2006). Predictors of child welfare worker retention and performance: Focus on Title IV-E funded social work education. Journal of Social Service Research, 32(3), 67-85. doi: https://doi.org/10.1300/J079v32n03_04

Seroka, C., \& Zugazaga, C. (2008). One piece in the child welfare puzzle: Evaluation of Alabama public child welfare internships and subsequent employment. Journal of Baccalaureate Social Work, 13(2), 83-96. doi: https://doi.org/10.5555/basw.13.2.fm7127t642784650

Siefert, K., Jayaratne, S., \& Chess, W. A. (1991). Job satisfaction, burnout, and turnover in health care social workers. Health \& Social Work, 16, 193-202. doi: https://doi.org/10.1093/hsw/16.3.193

Strand, V. C., Dettlaff, A. J., \& Counts-Spriggs, M. (2015). Promising innovations in child welfare education: Findings from a national initiative. Journal of Social Work Education, 51(sup2), S195-S208.

Strolin-Goltzman, J. (2010). Improving turnover in public child welfare: Outcomes from an organizational intervention. Children and Youth Services Review, 32(10), 13881395. doi: https://doi.org/10.1016/j.childyouth.2010.06.007

Tracy, E. M., Bean, N., Gwatkin, S., \& Hill, B. (1992). The family preservation workers: Sources of job satisfaction and job stress. Research on Social Work Practice, 2, 465478. doi: https://doi.org/10.1177/104973159200200403

Weaver, D., Chang, J., Clark, S., \& Rhee, S. (2007). Keeping public child welfare workers on the job. Administration in Social Work, 31(2), 5-25. doi: https://doi.org/10.1300/J147v31n0202

Webb, C. M., \& Carpenter, J. (2011). What can be done to promote the retention of social workers? A systematic review of interventions. British Journal of Social Work, 41(7), 1-21. doi: https://doi.org/10.1093/bjsw/bcr144

Williams, S. E., Kirk, A., \& Wilson, T. (2011). A recent look at the factors influencing workforce retention in public child welfare. Children and Youth Services Review, 33(1), 157-160. doi: https://doi.org/10.1016/j.childyouth.2010.08.028 
Willis, N., Chavkin, N., \& Leung, P. (2016). Finding "health” and “meaning” in Texassized turnover: Application of seminal management principles for administration and research in U.S. public child welfare agencies. Advances in Social Work, 17(2), 116133. doi: https://doi.org/10.18060/20856

Zlotnik, J. (2002). Preparing social workers for child welfare practice: Lessons from an historical review of the literature. Journal of Health \& Social Policy, 15(3/4), 5-21. doi: https://doi.org/10.1300/J045v15n03_02

Author note: Address correspondence to: Barbara Pierce, PhD, LCSW, School of Social Work, 902 West New York Street, Indiana University, Indianapolis, IN, 46202. 